\title{
Problems Involved in Improving the Quality of Life in Albania in the Years 2000 - 2012
}

\section{Dr. Enriko Ceko}

\author{
Doi:10.5901/mjss.2013.v4n10p312
}

\begin{abstract}
There are some major issues to be clarified about the quality of life in Albania. The standard of living as reflected by GDP and GDP per capita do not give the full picture of the quality of life in Albania. The indicators of standard of living given by GDP and $G D P$ / capita do not show the real quality of life. The purpose of this research is to identify the problems about defining quality of life through accounting and to improve the reliability of parameters to be used. The methods used in the research are gathering figures, information, data, comparison of data with other countries, revealing results, giving recommendations. The main conclusion of the research is that in Albania most of the indicators of quality of life are not reliable and cannot be used to draw conclusions about the quality of life index. Citizens' level of education about the quality of life is low. Improving the quality of life is the basic and a major goal for a real guarantee on Albania's integration into regional, European and wider structures.
\end{abstract}

Keywords: Albania, GDP, quality of life index, Indicators.

\section{Introduction}

The object of this study is to define problems involved in improving the quality of in Albania for the period 2000 - 2012 and provide some ideas and thoughts about changing the current situation.

The aim of this study is to show level, procedures and deficiencies in the process of determining the quality of life in Albania. The method of conducting this study is the analysis of situation and on this basis drawing conclusions and recommendations, using official data and information from primary sources such as international and national institutions.

\section{Methods}

The methods used in the research are gathering figures, information, data, facts from (only) primary resources, processing them and making comparisons with other countries, writing the first draft of the paper, revising it several times, writing the final version of the paper, revealing conclusions and results, and under that base giving recommendations. The main hypotheses of the research were the question on the reliability of last years GDP figure of Albania. As per research the last years GDP of Albania is not a reliable figure, since there is not any evidence of proper calculation of this figure, because main sectors of the country's economy are suffering problems and the measurement method for them is in question.

\section{Results}

In Albania there are no independent bodies that determine the level of quality of life and no reliable data on the level of quality of life, while there are some public bodies which measure its indicators and, which publish the figures and data for the country, economy, environment, health, population, etc, but these figures are not accurate. These figures have been used by international organizations for their reports, including those related to quality of life. Creating conditions whereby figures and data on quality of life in Albania come from independent bodies is an immediate requirement, increasing the reliability of figures and data on quality of life in Albania, to create conditions for a greater commitment to an improvement in quality of life and to make decisions for a fairer and more suitable performance and development.

\section{Discussion}

The Contemporary notion of quality of life is the exchange that follows the individual, and the level of personal choice that contribute to the creation of his personal identity amongst others. It was, for example, John Locke who promoted the individual's natural rights for life, liberty and prosperity, including efforts to seek happiness as an individual order, 
stressing that humanitarian conditions include experiences of being human in social, cultural and personal context. This has to do with human nature and the conditions under which life is created and the human being passes the life (5).

Human needs are an amalgam of the concepts of survival, reproduction, security, vacations, understanding, participation, creativity, identity, freedom, and so on.

To achieve these, a certain level of human and social capital must be established. People have different perceptions of what constitutes quality of life and this is a function of their age, social class, and their particular conditions..

\subsection{What is the quality of life}

Quality of life relates to emotional state and personal life, but there are some other important aspects to have a good quality of life such as personal and collective safety, health, infrastructure, the availability of consumer goods, adequate housing, education, opportunities for vacation, and so on. Quality of life reflects the combination of environmental, political, social and economic factors. Quality of life factors are inter alia positive support for the individual, family, and community.

This concept is closely linked to the Meta-Motivation Theory of Maslow, who described the motivation of people who are self-actualized, designed to put forward, beyond their basic needs to achieve their full potential. People below the self actualization stage seek to achieve basic needs or have reached some, but not all of these goals during their lives). People who work towards meeting self actualization, want to reach their potential through Maslow's MetaNeeds: List) supplementation (unity), excellence (balance, harmony), completion (end), fairness, complexity, simplicity , spontaneity, beauty, grace, individuality, convenience, truth (reality), autonomy (self efficiency), understanding (value), etc. (1).

\subsection{The importance of measuring the quality of life}

Real measurement of quality of life is of great importance because the quality of life indicators allow governments to understand and assess the actual situation against their objectives or with the quality of life in other countries. For this, a number of objective and subjective indicators have been used, most of them from different disciplines, including social - psychological indicators. These indicators, together with the concepts of freedom, human rights, happiness, etc, rather difficult indicators to measure have been seen and/or has been given special credence in the last ten years at international level.

Objective factors are measurable in economic and statistical terms, while subjective factors are dependent on data gathered from individuals that together make evaluation of these factors. Many of these important factors relate to data a real numbers but are also rely on peoples' own perceptions of their general situation. This may be so, because (a) the perception of people may not be a reflection of reality, (b) it may be that even though the perceptions of people are real, those processing the data may not be able to draw accurate and clear conclusions about these perceptions and factors derived from them, etc.

Thus, the following may skew the results or lead to erroneous conclusions: wrong indicators, wrong interpretation, incorrect comparison (for example: comparison of purchasing power when the two countries have different market baskets), errors in data or in the method analysis, use of old data, inappropriate extrapolation, ignoring variability, and so on.

\subsection{Models for measuring quality of life}

Today countries around the world apply several models for measuring the quality of life, based on an interdisciplinary loop and data from sectors of the economy, education, health, environment, public safety.

Some of these models are:

1. Quality of life indicators Calvert-Henderson

2. Mercer Index

3. Popsicle Index

4. Human Development Index

5. Canadian Welfare Index

6. Planet of Happiness Index 
7. Quality of life index of The Economist Intelligence Unit

8. Quality of life index of International Living

Almost all these indices use measurements which take into account conditions and progress in terms of education, employment, energy, environment, health, human rights, income, infrastructure, national security, public safety, recreation, housing, Thus, social indicators of human welfare are worked out based on the results of the quality of life indices and show life expectancy and health. He aim would be to improve this through greater incomes. The assumption here is that health and positive experiences are universal concepts and are attained through the correct use of natural resources and other basic inputs.

A successful society supports the livelihood of individuals while minimizing the cost to the environment. These are the objectives and aims of Clinton's - "Green GDP" initiative (3) and Sarkozy's - "Calculation of the integrated environment \& economy" initiative (14).

Based on these two initiatives, in June 2007, the World Forum "Statistics, Knowledge and Policy" - Measuring and Fostering the Progress of Societies, organized by the OSCE (9), has paid a great deal of time and attention and to measure support and the progress of societies. This has been achieved by improving policy making, democracy and the welfare of citizens, encouraging people to determine what constitutes progress, to identify best practices in measuring the progress by stimulating international debate on the progress and the creation of statistical capacity to understand the changes.

In November 2007, the European Community (EC), European Parliament (EP), Club of Rome, the OSCE (OECD) and WWF, the international conference undertook to determine which indicators)should be used to measure progress and integrating these indicators into the decision-making process (10). In this conference the political decision was made to go beyond GDP indicators to include the use of time indicators, governance, psychological wellbeing, community vitality, community life, political stability, security and health at work, unemployment, freedoms, human rights and gender equality to name, etc.

\subsection{Sustainable development and quality of life}

Sustainability is a set of conditions and trends that may continue indefinitely. Sustainable development is a strategic process of constant change in terms of sustainability and has to do with standard of living, income, quality / validity of employment, inequality of classes, the percentage of poverty, quality / availability of housing, working hours be carried to purchase basic commodities, inflation, number of paid holidays per year, access to affordable quality health care, quality I availability of education, life expectancy, morbidity, cost of goods and services, infrastructure, economic growth, economic stability / political freedom political / religious, environmental quality, climate, security, etc.

While, quality of life, in addition to the above, relates to freedom from slavery and torture, equal protection before the law, freedom from discrimination, freedom of movement, freedom to live in the host country, the presumption of innocence, the right of marriage, the right to have a family, right to equal treatment regardless of gender, race, language, religion, political affiliation, social and economic situation, the right to privacy, freedom of thought, religion, free choice of employment, payment of fair and equal for equal work, the right to vote, holidays , the right to education, the right to human dignity, and so on. These are rights which have been important in Albania in the past and on which international organizations place great importance.

\subsection{Quality of life, gross output and GDP per capita}

One of the key indicators included in the calculation of the index of quality of life is the concept of national income, the distribution of income, level of informal economy. For these, it is essential that the data be reliable.

We note that accumulating wealth enables the individual and society to fulfill their aspirations A society may not be democratic but if it is rich, the members of that society may be respected even though the family itself is not wealthy..

The gross domestic product is the sum of consumption expenditures, investment, government purchases and the value of exports minus imports. This shows the income and expenses with a material value because each seller has a buyer. Any money spent by a buyer is money earned by a seller. Economic growth is growth of production and consumption of goods and services. Economic growth means that the economy becomes larger, but not necessarily better. Economic growth might not produce happy people, healthy ecosystems, vibrant communities or opportunities for employment. Economic growth may not bring economic development. Growth of GDP does not mean that there is a justice or equity in income distribution among its citizens. 


\subsection{Quality of life index and the case of Albania}

Since Albania is into the turning point of a transition phase, it is very important to understand that during the emergency phase the main issue was to raise revenues and not the quality of life, while in further stages of development it is the quality of life which is the main aspect of development. This is measured by the skills to make healthy humans, to have educated individuals who have self-respect and actively participate in areas of concern to the community and their future, increasing the ability of individuals to be free to choose which in turn leads to increasing prosperity.

Albania has made progress in relation to quality of life. Referring to the Human Development Index for the period 2000 - 2011 it ranked among 68 to 78, where previously it was on level 80 (15). According to The Economist Intelligent Unit (11), Albania has climbed 20 places and the country ranked 53 (2010), compared with 73 (2005 and 2007). In rankings of happiness, the Albanians, for the period 2000 - 2009 ranked 38th place (16). Even according to International Living (12) for the period 2009 to 2010, Albania has made progress, ranking the country 52 . But these indices have been based mainly on gross domestic product and gross domestic product per capita, as well as on education and longevity.

The fact is that in the past ten years, Albania has had a positive economic growth, which for the period 2000 2008 has been averaging $6 \%$, while for the last three years $2009,2010,2011$ the average has been $3-3,5 \%$. GDP per capita has increased to $\$ 7800$ - 8000 in 2010, compared with $\$ 6300$ of the period 2007 - 2008 (7).

Albanian GDP has been made up of approximately $20 \%$ from the agricultural sector, $20 \%$ construction sector, $30 \%$ the service sector (where tourism plays an important role), 10\% the industrial sector, $10 \%$ transport and $10 \%$ from other economic activities (7).

For the agricultural sector regular increases in agricultural production of an average of 8\% each year (1993 - 2010) have been reported. For the year 2011 the government has declared a greater increase, which makes agriculture contribute about 30\% of GDP (See chart1). As a matter of the fact, it is very well known that agricultural production is subject of The Minimum Factor Theory (Liebig's Law). In Albania, agricultural land has not been increased recently, it has 704,000 hectares left according to the figures, but in fact only 388,000 ha has been cultivated by farmers. Also, the number of farms has been declining. For the period 1998 - 2008 the number of farms which use fertilizers has declined and the amount of chemical fertilizer use has reduced by about 124,000 tons in 2001 to 103,000 tons in 2009. The Chemical fertilizers which have decreased in use are ammonium nitrate and super phosphate (4) (See Graphic 2 and Graphic 3).

As far as the tourism sector is concerned, in 2010 it was declared that about 3.5 million tourists (staying an average of 10 days) came to Albania and spent an average of 100 Euro per day. Roughly the same situation was reported for the summer tourism season of 2011 and 2012. When asked how the figure of the average daily expenditure of tourists had been there has been no response from official sources (8).

A quick analysis of these two sectors, agriculture and services (tourism) shows that the GDP figure is somehow not appropriate for calculating the index of quality of life in the case of Albania. Moreover, for other figures dealing with education, health, energy, etc, in Albania there is no any independent organization, willing or capable of calculating, processing and declaring figures which might challenge those figures of the Institute of Statistics, a government controlled agency.

For 2013, Albanian Government has declared an economic growth of about 4\%, based mainly in agriculture and construction development. While in agriculture the situation remain the same with last years (explained above), the constriction still is a problematic sector with a very low level of construction permits. Government has about 50 million Euro debts to construction firms for job done through civil works during 2008 - 2012, which has not been paid yet (16), while a GDP $\$ 9300 /$ head/2012 has been declared by Prime Minister of Albania, during a meeting with journalists (17), an increase of about 20\% compared with 2011.

There is a lack of data about health and environment sector, while several main economic indicators like unemployment are subject of grave debates between Government, which declares a level of about $13 \%$ in last 10 years and the opposite that pretends for a level of about $40 \%$.

Also, the fact remains that the country lacks social cohesion, based on gender, economic and regional equality, and neither is there any great knowledge among the population at large for this concept (2).

\section{Conclusions}

1. In Albania there are no independent bodies that determine the level of quality of life and no reliable data on the level of quality of life. 
2. In Albania there are some public bodies which measure its indicators and, which publish the figures and data for the country, economy, environment, health, population, etc.

3. Figures and data of governmental bodies are not accurate. This is especially true of GDP, which is still one of world's most important elements for calculating the index of quality of life.

4. Figures and data obtained by governmental organizations have been used by international organizations for their reports, including those related to quality of life.

\section{Recommendations}

1. Creating conditions whereby figures and data on quality of life in Albania come from independent bodies: This is an immediate requirement.

2. Increasing the reliability of figures and data on quality of life in Albania will create conditions for a greater commitment to an improvement in quality of life and to make decisions for a fairer and more suitable performance and development.

3. The GDP figures do not reflect the standard of living and quality of life in Albania.

4. Quality of life in Albania is still a new concept amongst and across various sections of the population.

5. Albanian society, for various reasons, is still unprepared to deal with the issue of quality of life.

\section{References}

A.H. Maslow. A Theory of Human Motivation \& Motivation and personality

Ceko Enriko. When social cohesion doesn't exist. Article published at Newspaper "Shqip".

Green GDP Accounting Study Report 2004

INSTAT, Albanian Institute of Statistics. Tables about agricultural sector. www.instat.org

Lock John. Essay Concerning Human Understanding, Second Treatise of Government, and Letter on Toleration.

Ministry of Finance of Albania. Table of macroeconomic indicators

Ministry of Tourism of Albania. Press Conference for Tourism sector development during 2010.

World Forum "Statistics, Knowledge and Policy" - Measuring and Fostering the Progress of Societies, OSBE, June 2007.

World Forum "Defining quality life indicators" European Community (EC), European Parliament (EP), Roma Club, OECD and WWF, November 2007.

The Economist Intelligence Unit. Quality Life Index 2005 - 2010

International Living. Quality Life Index 2010

Future yield growth in field crops: what evidence exists? (Liebig's Law)

Report of the commission on the measurement of economic performance et social progress (Sarkozy Initiative)

UNDP. Human Development Index. 2000 - 2009

UNDP. Happiness Index

Parliament meeting of 6 December 2012

PM Sali Berisha's meeting with journalists, 26 December 2012.

\section{Appendices}

Happiness

Possible ranges

Highest score

Albania

Lowest score

Average
Happiness
$0-10$
8.5
4.6
2.6

Happy Life
Years
$0-100$
66.7
35.2
12.5

Inequality Adjusted
Happiness
$0-100$
79
38
19

Table 1. Happiness in Albania. Current happiness: place on rank lists of Happiness in nations 2000-2009. UNDP

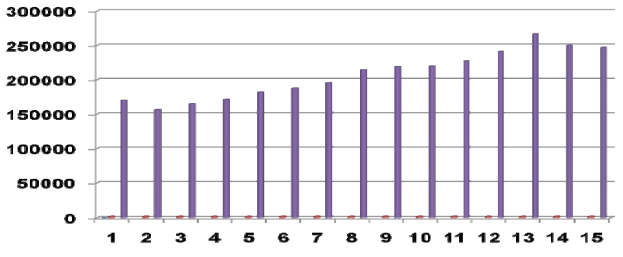


Graphic 1. Agriculture production increase in thousands of Lek (1996 - 2010), INSTAT

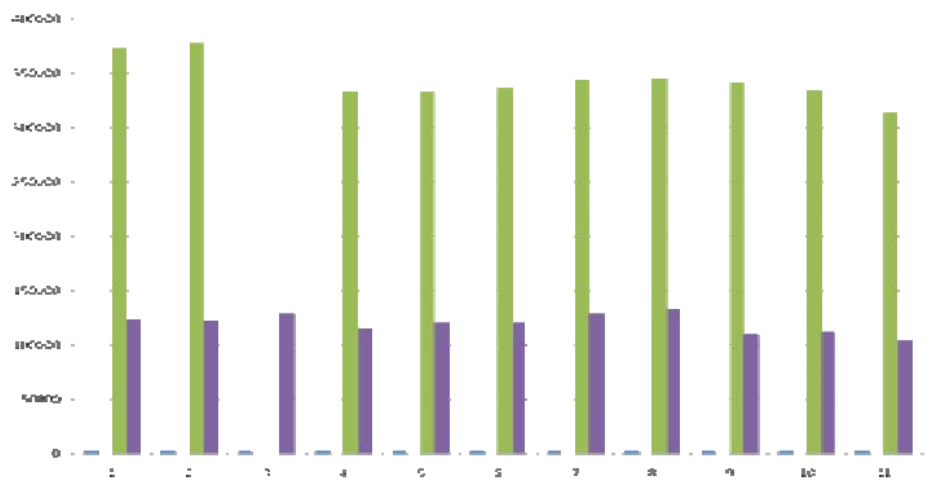

Graphic 2. Number of farms using chemical fertilizers and the amount of fertilizers used (1998 - 2008), INSTAT

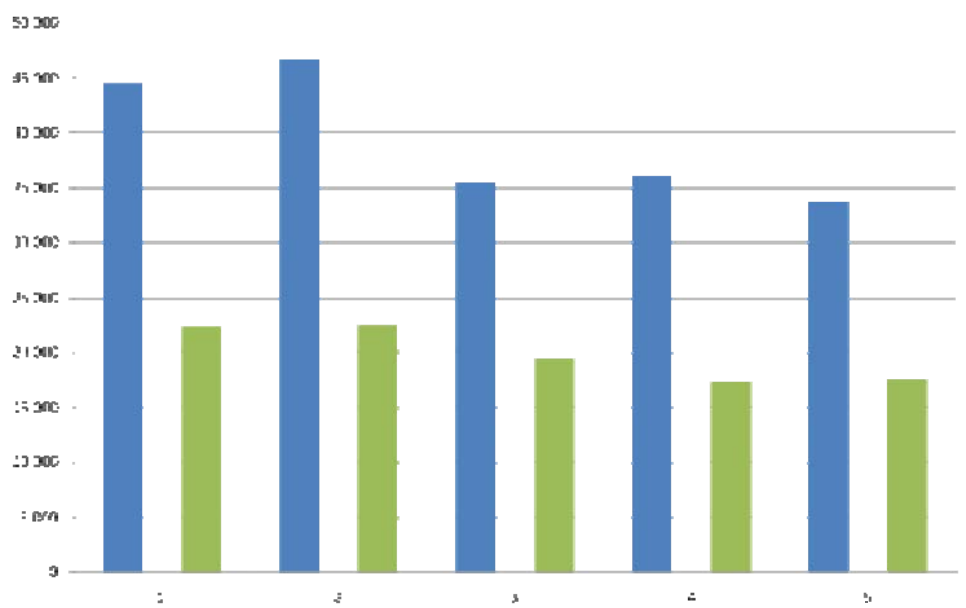

Graphic 3. The level of superphosphat (blue) and ammonium nitrate (green) used by farmers in tons (1998 - 2008) INSTAT 